University of Massachusetts Amherst

ScholarWorks@UMass Amherst

Published Work

Center for Student Success Research

2018

\title{
"Black elephant in the room": Black students contextualizing campus racial climate within U.S. racial climate
}

\author{
Chrystal A. George Mwangi \\ University of Massachusetts Amherst \\ Barbara Thelamour \\ College of Wooster \\ Ijeoma Ezeofor \\ Harvard University \\ Ashley Carpenter \\ University of Massachusetts Amherst
}

Follow this and additional works at: https://scholarworks.umass.edu/cfssr_publishedwork

\section{Recommended Citation}

George Mwangi, Chrystal A.; Thelamour, Barbara; Ezeofor, Ijeoma; and Carpenter, Ashley, "'Black elephant in the room": Black students contextualizing campus racial climate within U.S. racial climate" (2018). Journal of College Student Development. 24.

https://doi.org/10.1353/csd.2018.0042 
"Black elephant in the room": Black students contextualizing campus racial climate within U.S. racial climate

\author{
Chrystal A. George Mwangi \\ Barbara Thelamour \\ Ijeoma Ezeofor \\ Ashley Carpenter
}

Chrystal A. George Mwangi is Assistant Professor of Higher Education at the University of Massachusetts, Amherst.

Barbara Thelamour is Assistant Professor of Psychology at the College of Wooster.

Ijeoma Ezeofor is a graduate student in Public Health at Harvard University.

Ashley Carpenter is a doctoral candidate of Higher Education at the University of Massachusetts Amherst.

For the published version of this article, please visit:

George Mwangi, C. A., Thelamour, B., Ezeofor, I., \& Carpenter, A. (2018). "Black elephant in the room-" Black students contextualizing campus racial climate within U.S. racial climate. Journal of College Student Development, 59(4), 456-474. 


\begin{abstract}
The systemic racism in U.S. society being resisted through larger movements such as Black Lives Matter is also reflected and reproduced in U.S. higher education. This qualitative study examines how Black students contextualize their campus racial climate within broader race issues, tensions, and movements occurring across the nation. Findings reveal four themes: (1) Perceptions of Blackness on campus; (2) Campus racial climate mirroring societal racial climate; (3) Experiencing and engaging in movements on campus; (4) Impact of racial climate on future planning.
\end{abstract}


Universities are experiencing increased pressure to demonstrate their utility to society, meet the demands of increasingly diverse students, and engage in the application of knowledge and research towards solving societal problems (Tierney \& Perkins, 2015). Given this context, it is important for higher education to remain connected to the issues of the local, national, and global communities in which they are located as well as prepare students to positively engage in these communities. Conversely, scholars often reify the "ivory tower" image by conducting higher education research that is disconnected from the broader societal context within which universities are situated (Hurtado, Alvarez, Guillermo-Wann, Cuellar, \& Arellano, 2012).

Our study stems from this inconsistency by examining the interplay between U.S. societal racial climate and campus racial climate for Black students. Scholars clearly demonstrate that Black collegians are more likely to have negative assessments of campus climate than their peers of other races (Ancis, Sedlacek, \& Mohr, 2000; Rankin \& Reason, 2005; Suarez-Balcazar, Orellana-Damacela, Portillo, Rowan, \& Andrews-Guillen, 2003). Research also demonstrates how universities are working to improve campus racial climate by developing targeted campusbased interventions (Hurtado et al., 2012). Yet, what is missing from this research is how broader U.S. society's racial climate impacts (and is impacted by) racial climate on campuses as part of the student experience. The $21^{\text {st }}$ century U.S. racial climate demonstrates growing pessimism regarding race relations, increased public visibility of police brutality towards Black people, and growing empirical evidence of the implicit anti-Black racial bias that exists in U.S. society (Bonilla-Silva, 2017; Swift, 2017). Simultaneously, this climate reflects the growing strength of movements for racial justice and the fight against anti-Blackness, including the Black Lives Matter movement (Bonilla-Silva, 2017). As Black college students see this racial climate reflected in social and news media, experience their racialized identities being connected to 
broader systems of oppression, and engage in race activism, the lines between racial climate in the U.S. and on campus become blurred. Thus, the interplay between the macrostructural U.S. racial climate and the microstructural campus racial climate must be acknowledged and investigated in order to fully understand Black students' experiences. Our study centers on this issue and poses the research question: How do Black students contextualize campus racial climate within the broader racial climate of U.S. higher education and society?

Engaging this question is important, given that in a study by the American Council on Education, over 55 percent of college presidents stated that racial climate has become more of a priority than it was three years ago and 75 percent believe high-profile events such as \#Black LivesMatter increased campus dialogue (Espinosa, Chessman, \& Wayt, 2016). When Black students respond to negative campus racial climate by creating lists of demands or engaging in protests, it is not a-contextual from racial tensions in broader society. Our study explicitly demonstrates how universities and broader society are inextricably linked regarding race and racism. If universities are only looking inwards to find solutions to the challenges and barriers their Black students have regarding racism, they will be leaving out key external factors that play a role and that inform how race and racism are enacted on campus. Furthermore, systemic racism is reflected in U.S. higher education institutions, and these institutions can act as agents in the social reproduction of inequality as well as act as agents for positive social change. Thus it is important that institutions are aware of how they reflect, reify, resist racism in broader society.

\section{Literature Review}

Students of Color have a history of marginalization, discrimination and isolation within higher education (Edman \& Brazil, 2007; Hurtado \& Ruiz, 2012; Solórzano, Ceja, \&Yosso, 2000; Yosso, Smith, Ceja, \& Solórzano, 2000). Although universities seek to increase structural 
forms of diversity to improve the representation of People of Color, this does not always improve racial climate (Author, 2016; Rankin \& Reason, 2005). Research suggests that many Students of Color feel disconnected from their campuses and experience an unwelcoming academic climate (Hurtado \& Ruiz, 2012; Johnson et al., 2007; Solórzano et al., 2000). This reality is further exacerbated when scholars look at the specific college experiences of Black students.

For example, scholars report that Black students have negative perceptions of their campus climate due to racial/ethnic hostility, inequitable treatment, microaggressions, isolation, tokenization, lack of representation, and overt racism (Ancis et al., 2000; Author, 2016; Harper \& Hurtado, 2007; Johnson et al., 2007; Rankin \& Reason, 2005; Solórzano et al., 2000). Perceptions of their institutional environment impact students' overall campus experiences (Rankin \& Reason, 2005). For example, negative perceptions of campus racial climate contribute to isolation (Solórzano et al., 2000; Yosso et al., 2009) and diminish sense of belonging and institutional commitment (Johnson et al., 2007; Cabrera \& Nora, 1994). Negative perceptions of campus racial climate influences a number of student outcomes, including retention, academic success and graduation (Edman \& Brazil, 2007; Hurtado \& Ruiz, 2002; Solórzano et al., 2000). Isolation and sense of belonging are two of the most prevalent issues discussed when addressing campus climate for Black students (Johnson et al., 2007).

Literature on the experiences of Black students clearly demonstrates the impact that campus racial climate has on their college experiences and well being. Yet, while the racial issues described in earlier studies continue to exist at predominantly White institutions (PWIs), today's Black students are now using tools such as social media that connect them to information about racial injustice beyond campus walls and students are engaging in (inter)national Black movements such as Black Lives Matter (Black Liberation Collective, 2016; Howell, 2016). Still, 
there is little literature that considers the interplay between students' experiences, campus racial climate, and the racial climate of broader U.S. society (Mendez \& Cabrera, 2015). Our study engages this knowledge gap by investigating how Black students contextualize their campus racial climate within broader race issues, tensions, and movements.

Much of the work on Black students' experiences with campus racial climate reference or are framed using Hurtado et al.'s (1998) original framework. However, this framework has since been revised by Milem, Chang, and Antonio (2005) and Hurtado, Alvarez, Guillermo-Wann, Cuellar, and Arellano (2012). These revisions have further integrated structural/organizational and external contexts to understand campus climate. Given our interest in the connection between campus and U.S. racial climate, we extend the literature on Black students' experiences with campus racial climate by framing our study using multi-contextual model for diverse learning environments (DLE) developed by Hurtado and colleagues (2012).

\section{Conceptual Framework}

The DLE was informed by research on the educational experiences of Students of Color and provides a holistic framework for understanding campus climate, university practices, and student outcomes (Hurtado et al., 2012; Hurtado \& Guillermo-Wann, 2013). It draws upon the developmental ecological work of Bronfenbrenner (1979) and Renn (2003) and "is much more explicit than previous models about the multiple contexts at work in influencing institutions of higher education and student outcomes for the twenty-first century" (Hurtado et al., 2012, p. 48) Contexts are embedded within structures (e.g., historical, political, economic, cultural, and institutional environments), and these structures contribute to the shaping of individuals' learning and identity (Bronfenbrenner, 1979, 2005). The DLE is particularly relevant to understanding the racialized experiences of Black students because it considers multiple systems and contexts as 
well as whether and in what ways structural, contextual, and other related factors impact the educational experiences and outcomes of Black students at PWIs.

Hurtado et al. (2012) note that racism, a pervasive system of oppression across U.S. society, is interwoven with the institutional dimension of campus climate. Thus, the DLE integrates the five elements of the original campus racial climate model (Hurtado et al., 1998): (1) historical legacy of inclusion or exclusion; (2) organizational and structural dimension; (3) compositional diversity; (4) psychological dimension; and (5) behavioral dimension. However, the DLE expands the institutional context of the original campus racial climate model to further acknowledge students' experiences with their university's climate for diversity. Situating a student's identity at the center of their institutional experience, the DLE suggests that identity is directly connected to students' curricular and co-curricular engagement (Hurtado \& GuillermoWann, 2013). These compounded experiences help to explain student outcomes (e.g., retention, multicultural competency, and the achievement of larger societal goals such as social equity). In particular, the model illustrates the relationship among campus climate, diverse educational outcomes, and diversity, while focusing on equity and civic competencies (Hurtado \& Guillermo-Wann, 2013). The DLE highlights the educational benefits of diversity and implores institutional leaders and key stakeholders in student success to assess their campuses for diversity and inclusiveness within the student body.

This DLE is particularly relevant to our study because it demonstrates that campus climate is situated within the local/national community, policy arena, and socio-historical contexts within which an institution operates. According to Hurtado et al. (2012), "the organizational [and structural] dimension of the [campus] climate can be understood as reflecting the pervasive, systemic, and ordinary nature of racism in American institutions and perpetuate 
inequity through status quo processes in education" (p. 60). With this in mind, we seek to examine the experiences of Black students as they navigate their campus environment within the context of racial issues and tensions occurring in broader society.

\section{Methods}

The data comes from a larger mixed methods project on the educational experiences of Black American and Black immigrant college students. However, in reviewing the qualitative data there was a strong emphasis among participants on how they navigated campus racial climate given the broader context of racial tensions, racism, and racialized incidents occurring across the U.S. While this broader U.S. societal context was not captured in the quantitative survey, the qualitative narratives on the topic were so powerful that they warranted in-depth analysis. Thus, in this article, we focus on the qualitative narratives emerging across Black students' experiences with campus racial climate as situated within larger U.S. racial climate.

\section{Study Recruitment and Sample}

We recruited a sample of participants that: (1) identified as Black; (2) undergraduate student (current student or graduated within past two years); (3) attends or attended a PWI in the U.S. Participants were targeted via a recruitment email that was distributed to campus organizations that commonly target/work with Black students and snowball sampling. The recruitment flyer invited students to take an online survey (resulting in 351 participants). At the end of the survey, participants opt into an individual interview, which yielded 25 participants (see Table 1 for interview participant demographic characteristics).

Table 1. Participant Characteristics

\begin{tabular}{|l|l|l|l|l|l|}
\hline Pseudonym & Gender & $\begin{array}{l}\text { Preferred Racial- } \\
\text { Ethnic Identity }\end{array}$ & $\begin{array}{l}\text { Additional Self- } \\
\text { reported Identities }\end{array}$ & Region & $\begin{array}{l}\text { Student } \\
\text { Status }\end{array}$ \\
\hline Jen & Female & $\begin{array}{l}\text { African Am. and } \\
\text { Puerto Rican or } \\
\text { Latina }\end{array}$ & None & Midwest & Senior \\
\hline
\end{tabular}




\begin{tabular}{|c|c|c|c|c|c|}
\hline Donna & Female & African Am. & $\begin{array}{l}\text { Gender, sexual } \\
\text { orientation }\end{array}$ & Midwest & Junior \\
\hline Aisha & Female & $\begin{array}{l}\text { Black and Caribbean } \\
\text { Hispanic }\end{array}$ & Gender & Northeast & Junior \\
\hline Monica & Female & Black & $\begin{array}{l}\text { Gender, } \\
\text { profession/major }\end{array}$ & $\begin{array}{l}\text { Mid- } \\
\text { Atlantic }\end{array}$ & $\begin{array}{l}\text { Recent } \\
\text { Graduate }\end{array}$ \\
\hline James & Male & Black & $\begin{array}{l}\text { Sexual orientation, } \\
\text { class, disability, } \\
\text { nationality }\end{array}$ & Midwest & $\begin{array}{l}\text { Recent } \\
\text { Graduate }\end{array}$ \\
\hline Nancy & Female & $\begin{array}{l}\text { African or } \\
\text { Black/African Am. }\end{array}$ & Religion & Northeast & Sophomore \\
\hline Sheila & Female & $\begin{array}{l}\text { Biracial (Black, } \\
\text { White Portuguese) }\end{array}$ & $\begin{array}{l}\text { Gender, profession/ } \\
\text { major }\end{array}$ & Midwest & Junior \\
\hline Alexis & Female & Black & $\begin{array}{l}\text { Class, sexual } \\
\text { orientation, gender }\end{array}$ & Midwest & Senior \\
\hline Gayle & Female & African Am. & Gender & Northeast & $\begin{array}{l}\text { Recent } \\
\text { Graduate }\end{array}$ \\
\hline Peter & Male & $\begin{array}{l}\text { Black, Nigerian, and } \\
\text { Ibo }\end{array}$ & $\begin{array}{l}\text { Religion, artistic } \\
\text { expression }\end{array}$ & Midwest & $\begin{array}{l}\text { Recent } \\
\text { Graduate }\end{array}$ \\
\hline Curtis & Male & $\begin{array}{l}\text { Nigerian Am. or } \\
\text { Black }\end{array}$ & Religion & Midwest & Junior \\
\hline Samantha & Female & Black & $\begin{array}{l}\text { Nationality, gender, } \\
\text { marital status, sexual } \\
\text { orientation, age, class }\end{array}$ & Northeast & Freshman \\
\hline Liz & Female & $\begin{array}{l}\text { Black and Nigerian } \\
\text { American }\end{array}$ & Gender, religion, class & Northeast & $\begin{array}{l}\text { Recent } \\
\text { Graduate }\end{array}$ \\
\hline Kelly & Female & Black Latina & $\begin{array}{l}\text { Religion, } \\
\text { profession/major }\end{array}$ & Northeast & Senior \\
\hline Gina & Female & Black & $\begin{array}{l}\text { Political, } \\
\text { profession/major }\end{array}$ & Northeast & Senior \\
\hline Rebecca & Female & Black and Jamaican & $\begin{array}{l}\text { Religion, U.S. region, } \\
\text { sexual orientation, } \\
\text { hair type }\end{array}$ & Northeast & Sophomore \\
\hline Howard & Male & $\begin{array}{l}\text { Black, African, } \\
\text { Nigerian-born } \\
\text { Ugandan, clan and } \\
\text { parents' tribes }\end{array}$ & $\begin{array}{l}\text { Disability, artistic } \\
\text { expression }\end{array}$ & Midwest & $\begin{array}{l}\text { Recent } \\
\text { Graduate }\end{array}$ \\
\hline Kim & Female & Black Am. & Gender, class & Northeast & Senior \\
\hline Robert & Male & $\begin{array}{l}\text { Black, Ghanaian, } \\
\text { Ashanti, Fante }\end{array}$ & U.S. region, athletics & Southeast & $\begin{array}{l}\text { Recent } \\
\text { Graduate }\end{array}$ \\
\hline Lauren & Female & Black & $\begin{array}{l}\text { Class, gender, sexual } \\
\text { orientation, disability }\end{array}$ & Midwest & Sophomore \\
\hline Ben & Male & African Am. & Intellect, aspirations & Midwest & Junior \\
\hline Candice & Female & Black & $\begin{array}{l}\text { Gender, class, marital } \\
\text { status, parent }\end{array}$ & Midwest & $\begin{array}{l}\text { Recent } \\
\text { Graduate }\end{array}$ \\
\hline
\end{tabular}




\begin{tabular}{|l|l|l|l|l|l|}
\hline Jill & Female & $\begin{array}{l}\text { Haitian Am. or Afro- } \\
\text { Caribbean Am. }\end{array}$ & Religion, class & Northeast & Junior \\
\hline Frank & Male & $\begin{array}{l}\text { African Am. with } \\
\text { Cheyenne descent }\end{array}$ & $\begin{array}{l}\text { Religion, gender, } \\
\text { military family }\end{array}$ & $\begin{array}{l}\text { Mid- } \\
\text { Atlantic }\end{array}$ & Senior \\
\hline Mariah & Female & Black & $\begin{array}{l}\text { Religion, class, big } \\
\text { sister }\end{array}$ & Midwest & Freshman \\
\hline
\end{tabular}

\section{Data Collection}

After completing the survey component of the mixed method study (measures captured the individual, interpersonal, and contextual factors contributing to their college experiences), participants were invited to do a 45-60 minute interview via the online conference platform, Zoom. The interviews explored survey themes in-depth to gain an understanding of experiences with and perceptions of sense of belonging, social networks and support, racial/ethnic identity development, academic motivations, well-being, and campus racial climate. Interviews utilized a semi-structured protocol and examples of interview questions include "How would you describe your transition to college?" "How would you describe your current level of satisfaction with your university?" and "How would you describe or evaluate diversity on your campus?" All interviews were recorded and transcribed with pseudonyms used to provide confidentiality.

\section{Data Analysis}

We used NVivo software to inductively and deductively code transcripts using the constant comparative method (Charmaz, 2006). We chose twenty deductive codes reflecting key concepts from the interview protocol and conceptual framework. A priori codes included psychological, structural, historical, and behavioral aspects of campus racial climate (Hurtado \& Guillermo-Wann, 2013). In addition, we open coded the data using inductive codes emerging from the patterns within the narratives. To do so, as we read through transcripts, we made annotations at lines in the text that appeared useful in answering the research question. Examples 
of inductive codes include: Being the only one, Black campus activism, and Racial allies.

We employed the constant comparative method to construct axial findings by drawing together open codes to form patterns and themes (Charmaz, 2006). For example, we had open codes that reflected how participants believed Black students were perceived on campus. In reviewing these codes, we saw that they were related and therefore placed each within a category called Perceptions of Blackness. Through this process we developed four broad categories that are used to organize the Findings section. Overall, campus racial climate as a microcosm of U.S. societal racial climate emerged as a prominent storyline across the participants' interviews, as well as how participants perceive Black student engagement in issues of race and racism and the impact of these issues on their academic and career plans.

\section{Ensuring Trustworthiness}

Findings were consistent across the different contexts (e.g., geographic regions) of the participants. However, we recognize that the themes identified may be different for other Black students. We used a constructivist lens to emphasize students' experiences and perspectives and increased the study's transferability through detailed methods and the use of thick, rich description throughout our findings (Krefting, 1999; Lincoln \& Guba, 1985).

Considering positionality and engaging in reflexivity (e.g., the process of selfexamination and self-disclosure) are crucial parts of qualitative research (Krefting, 1999). We as researchers acknowledge that our identities intersect with the study and shape our perceptions of the data. The research team includes one doctoral candidate, one education practitioner, and two faculty members. All of the researchers identify as Black women, with three researchers also having an immigrant heritage. Given our positionalities, who we were and how we were perceived provided benefits and challenges in working with the participants and analyzing data. 
We worked to ensure trustworthiness by engaging in reflexivity. For example, as a research team we engaged in reflexive dialogue throughout the study about what we were experiencing and to ensure our interpretations of the data were consistent across the group (Maxwell, 2005). We offered feedback to one another as we developed drafts of the findings, engaged in discussions regarding emerging themes, and provided data-based evidence to support interpretations.

When we disagreed on an interpretation, it was discussed as a team. For example, team members at first disagreed with whether to disaggregate our findings by demographic characteristics (e.g., gender, nativity/ethnicity, social class, religion), given that our data allowed for this. As Black researchers with multiple intersecting social identities, we did not want to perpetuate the fallacy that Black students are a homogenous group. In this case, we turned to the data and did some initial disaggregation to determine if there were major differences in how students described their experiences with this specific article's topic and found that the themes we were presenting were predominantly consistent across participants. However, we chose to provide demographic information on each of the participants to demonstrate the diversity within the sample (see Table 1) and, where applicable, within their narratives present quotes that address/intersect other social identities. At other times, when we struggled with how to interpret our findings, we turned to the DLE framework and extant literature as guides. Findings were revised based on new understandings the team formed as we addressed divergent interpretations of the data and collaborated to communicate an interpretation with which we all agreed.

\section{Findings}

Four themes emerged: (1) perceptions of Blackness on campus; (2) campus racial climate mirroring societal racial climate; (3) experiencing and engaging in movements on campus; (4) impact of racial climate on future planning. 


\section{Perceptions of Blackness on Campus}

In discussing campus racial climate, participants described how non-Black campus members perceive Black students. Some participants discussed their race being associated with fear. Jen explained that on her campus, "It's like [White people] they stereotype, they see us, they fear Black women, they fear Black men. It still happens.” Candice furthered this point by saying, "They [White people] immediately seem on edge. They think I'm going to become an angry Black woman real fast...sometimes I feel people are afraid of me.” Often participants were shocked and unsure of how to react to these perceptions. James described not knowing how to deal with, "People jumping when I'm turning corners or afraid to work in groups with me...I wasn't prepared to address it and handle it." The fear participants described regarding attitudes and stereotypes of Blackness could often result in negative, prejudicial, and/or violent treatment.

As most of the participants described being proud of their racial and ethnic identity, they were frustrated with the stereotypes they experienced. Howard exclaimed,

For something that I have zero control over, such as my race, or my skin color, I was born this way, I'm proud of it, and that's all there is to say about that. I don't understand how there can be so much hatred against something that somebody has no control over. This sentiment was felt by many participants and was summed by Aisha who expressed, "stop looking at the color of my skin, and treat me like a person.”

Participants also described how microaggressions, rather than overt racism, is what is shaping the contemporary campus racial climate as expressed by Monica, "There are different things you can do that say whether or not you align with, or you're sympathetic with People of Color. There's a lot of things besides 'I hate niggers' that communicate that kind of attitude." Alexis expressed the range of experiences that come with being Black on her campus, "There's 
certain things people don't say to you unless you're Black. It's everything from hair politics to sexual fetishization of Black women." James explained that the cumulative affect of racial incidents on campus not only impacts Black individual students, but the entire campus environment. He expressed, "Its like the black elephant in the room. That is the racial climate." James' description of campus racial climate as "the black elephant in the room" demonstrates how critical racial issues are on PWI campuses, but that there is a lack of effective and authentic engagement or acknowledgement of these issues on these campuses.

\section{Campus Racial Climate Mirroring Societal Racial Climate}

Participants were very attuned to the U.S. racial climate through the media and their own research; however, suggested that Whites could choose not to be engaged, as Monica described, I wake up in the morning and, whether or not I should, read up on the latest thing.

Ferguson is getting sued...I was reading about the processes of slavery. Some of that Willie Lynch stuff, and how that still affects people today... These [White] people don't either know or care why these things happen, why they matter.

In explaining how she purposefully reads about racial issues each day, this student alludes that White people can remain distanced from these issues. Similarly, Gina resented that her White friends would not attend a Black Lives Matter protest with her, "They don't care that their friend is Black and this is your friend that is being affected by that...That was a wake-up call...that just really got me, like I'm done.” Although participants discussed purposefully engaging in and educating themselves about national racial incidents and violence, they could not avoid it, even if desired, due to their race, as one student explained, "Then with all the things that were going on while I was at [college], like the murder of Trayvon or Tamir Rice or John Crawford III, that's just made me hyperaware of being Black." While participants felt as if their PWIs/White peers 
could tune out of the negative aspects of U.S. racial climate, they themselves could not.

Participants also discussed seeing the national racial climate as a clear reflection of issues going on in their lives and on their campuses. For example, Gayle explained,

I have to worry about the issue of getting home safely... If we get stopped, what's going to happen? I commute to campus, and I have to drive a long, about two miles worth, of a two-lane road. I don't like to drive on it at night. I have driven on it thousands of times, but the thousands of times that I've driven on it...we didn't have issues like Mike Brown, like Freddie Gray, like Sandra Bland, and I get worried about that. I don't think that for a lot of students who aren't of Color, they don't have to worry about those issues.

Curtis discussed fear of how he was being perceived in relation to the Trayvon Martin murder, I was walking home one night. I just had my hoodie up...this [White] couple, they were walking, ... This alleyway was very narrow. I couldn't really get past....I had to pretty much stay behind them. It was the instance of what can I really do, but I guess walk slow behind them which looks more suspect, because I have a hoodie up, I am Black. The lady just continued to look back, [as if to say] "what is he about to do?" [I thought] "I can't stay in this situation. This is very bad." I have seen what has happened on TV, what has happened in cases like Trayvon Martin with his hoodie up. That's what I thought of. Participants saw themselves reflected in the murders of Black men and women and experienced anxiety in what could happen to them in just walking around campus or driving home from class.

A number of students described how tension and brutality among police in broader society was also present between Black students and campus police at their universities, There was a huge issue with public safety officers... They were racially profiling Black [students], Black males because they thought they were [from the local community]. 
They were like running after them and it was like this huge deal...They were just like,

"You're from the town. You're a Black person that's menacing the [university]." (Kim)

Other students also described the tense relationship with campus police as an issue,

There's a lot of tension with the public safety officers and especially Black men.

There's a student that got attacked by a public safety officer because he thought that he didn't go here...[It] touches on the Students of Color because if you're perceived to be from the town then you get classist, racist treatment that they wouldn't do explicitly to another student. (Gina)

In addition to individual Blacks being targeted, participants described more police presence at events held by Black student organizations than other organizations, giving the perception that events held by Black students or having high Black student attendance could be problematic.

Another theme was the presidential election, which participants described as intersecting political climate and racial climate. Kelly explained that due to the racially charged language of presidential candidates, it was giving people greater license to engage in racist behavior,

Even Donald Trump, I feel like there's always been racism but now in this time, a lot of people are not afraid to say what's on their mind. Back in the day, people might have been like, "Keep it on the hush hush," they won't say it. Now people are saying whatever they want to say about Blacks, because they know nothing's really going to happen. Another student expressed, "Going places and seeing a Trump sign, or a Cruz sign, all of those things are uncomfortable for me." For this student, she would see these signs around the college town that she lived in. Thus, although some felt their campuses were trying to provide a positive racial climate, their surrounding communities often did not. Lauren discussed town-gown relations in explaining that the town her campus was in is, 
Full of rural people that don't make a lot of money, there's a lot of racist people that don't go to the college but are around it...I have bad problems with panic and anxiety, and it's to the point [that] I'm afraid of every truck that drives down the street because 9 out of 10 times, they're yelling things or throwing things at me as I'm walking down the street.

A number of participants expressed that the campus environment should be a place to reflect on these issues, but many found that their classroom spaces did not acknowledge them,

Last year, I struggled with all the stuff [that] was going on. BLM movement... A lot of the police violence happened...To read about that and then come to class and no one brings it up, that was difficult for me. I wanted a space to talk about those things. (Peter) When discussions did occur, participants expressed discomfort in how they were facilitated and the expectation that Black students represent their race. Jen explained, "whenever we talk about police brutality, the whole class is, '[Jen], what's your opinion?' Wait, there are other students here. You don't have to just ask me because I'm a Person of Color." Similarly Lauren explained, "There's always that classic instance of if we're talking about anything that has to do with race and students do that side-glance at you, expecting you to be that monolith voice when we move to class discussion on it."

Furthermore, students wanted their peers, faculty, and administration to acknowledge the role that the university played in reifying racial inequality. James explained how he connected the movement at the University of Missouri to his own college experience,

One of our faculty was like, "If that student who starved himself at Mizzou...if he was here, I would have to do something as a faculty member to support him and make sure he doesn't have to starve himself to get his point across."...I'm like, "Well what are you doing about us [himself and another Black student in his program]? We're not starving 
ourselves, but we are loudly advocating for ourselves and pointing out this shit is not okay. But we're still eating. Do we have to starve ourselves for us to be taken seriously?" Some students saw their campuses making efforts towards engaging racial issues, but felt it was not enough. For example, Samantha explained,

[My campus] has the signs all across the lawn and wanting Black students to know they matter, but Black students...they want more than just you posting signs. They want to see you act, and they don't want to hear that you have a plan. They want to see something going on now...That's where the clash is, because all they hear is rhetoric or see a sign.

Overall, participants drew a number of comparisons between what they saw happening across the country related to race (e.g., police brutality and tension, racially-charged political climate) being mirrored in what they saw on their own campuses. These were issues that they consistently encountered and thought about in both their academic and social campus engagement.

\section{Experiencing and Engaging in Movements on Campus}

Students described the impact that racial incidents in U.S. society had on them as one participant expressed, “when something happens - and something's always happening, like Mike Brown or Trayvon Martin - it feels very personal to me. It's definitely a very raw experience." Describing the experience as "raw" demonstrates the vulnerability and pain students carried. It was present in how they experienced university spaces and engaged with campus members.

For example, when race-related issues would happen in the news, it impacted participants' interactions with White faculty and peers. Sheila explained, "Black Lives Matter, there was something happening in the news [about it], and people are just very insensitive to these things even in front of me...It's been an experience for me to try to address microaggressions without being unprofessional." Racial microaggressions, insensitivity, and 
invalidation were heightened in campus spaces, particularly if a student was the only Person of Color. Liz illustrated this, "A lot of the times I was the only Black person. I remember having to feel like I was the spokesperson for Black people and that my experiences weren't valid." Sheila and Liz demonstrate that not only were students experiencing distress from race-related issues in broader society, but that the hurt was reified by a PWI campus that exerted racism and pressure. Outside of the classroom, many participants were also disheartened by their interactions with White peers. Donna explained,

I lost a friend last semester. He was a White male and we were talking about the Michael Brown thing in class and his reaction was, "He was a criminal. He got what he deserved," and we had this debate that ended our friendship. [I was] like, "You don't know the whole story either way. Even if he was or if he wasn't, no one deserves to die and sit there in the middle of the street. That's just common decency." That broke my heart because that was really one of my good friends... and so to completely lose that friendship over that debate was hard because I know there's other people who experienced that.

Similarly, after a conversation about Mike Brown, Howard expressed to his White peer, "No, you just said something very messed up, and I don't want to associate with you." The sentiments of feeling obligated to engage in conversations regarding racism and racial tensions in the U.S. was something many Black students felt they needed to do. Yet, as these examples suggest, it could change their relationships with White students.

These racist and racializing encounters contributed to and/or reinforced the desire among participants to engage in race movements. Students described participating in protests, sit-ins, walkouts, and die-ins, but these were not always well received on their campuses, We did marches for Mike Brown, Trayvon Martin, and I remember I was marching for 
Trayvon and we were on campus and we had our signs...Somebody yelled, "STFU," just very angry and people got so upset that we were marching through campus. (Sheila) Similarly Mariah, a student from a campus in the Midwest, was shocked by some of the rhetoric against campus activism, "we did a silent protest where we had tape on our mouths, and there's stuff like, 'Ooh, I'm glad somebody finally taped their mouths shut. They're so ignorant. Ugh, they're so rowdy.'" Gina also described that after a walk-out on campus,

Yik Yak blew up. A bunch of people sending messages about the protest and they were very hateful and openly racist. One of them was, "Somebody needs to come get their slaves." They said a whole bunch of things like, "I don't understand why all these Black people need to throw a temper tantrum every time one of them gets killed." It was really hateful, hurtful, racist, very racially charged comments on Yik Yak that day." As these students illustrate, the hate, ignorance, and racism that BLM protestors and other race activists experience in U.S. society was present at PWIs as students took an activist stance. Some participants explained that their White peers had a hard time understanding the significance of Black student activism, as some White students believed that they were not directly impacted. For example, Samantha described,

When we had the die-in, [the campus] ignored it until they saw that we were going to be there on the library floor. We were encouraged to stop and were told that we were being monitored. Because it was the week before finals, a lot of people were pissed off. A lot of people didn't think we needed to do this because it wasn't directly affecting students. This participant also recognized that some students might not agree with the tactics used, but it was important for them to still recognize the significance of the movement and stand in solidarity with one another. She said, "We should respect each other, but that doesn't happen if as I'm 
protesting something, people are telling me that my life is pretty much worthless."

Despite these negative experiences, students found race-related incidents opening up space for dialogue on their campus about race and racism as well as empowering students to engage in activist movements. James described that at a BLM march on campus,

To my surprise, a ton of people came. I was like, "Wow." It was just so heartwarming to see that even if seventy-eight percent of the people and the faces in the crowd were

White, that this was still something that could happen at [my campus].

Other students talked about how their universities were attempting to be more deliberate in their actions of supporting student activism. Curtis said,

I think that was really our moment to stand up to what is going on in our campus, which has sprung to some change. The change that we want is coming slowly, but it seems progressive, with a new president of the university who's having diversity talks and just hearing, any Person of Color or any one voice that feels marginalized.

Gayle also discussed university support, "During a program that our president was hosting, it was right after the Missouri issue, not only were students protesting outside, but our faculty were protesting." Thus, solidarity and initiatives for racial justice could be found at PWIs, particularly when administrators and faculty provided the support and resources needed to foster change.

\section{Impact of Racial Climate on Current and Future Engagement}

Participants discussed how their experiences with race and racism in college increased their desire to positively represent what they described as the Black community. Monica explained this, "I am part of a community that has all sorts of needs, and I have a responsibility as a person in that community, especially one who is in a place to make some change." Students saw themselves as part of a community they received support from and represented. 
Like Monica, many students described the responsibility that they had to the Black community. For example, Frank stated that being a part of this community,

Means you have to approach things in a way that an African American male is obligated to do so, in everything that you do. There [are] stigmas surrounding life as an African American that you have to one, battle, two, in some cases live up to, and live beyond. Alexis also reflected on her need to rise above stereotypes as part of her responsibility, You have this way you have to present yourself as being against what people would say is the stereotyped idea of what a Black person is. Instead of just living your life like, "Oh I'm just a human." It's like, "No, you are Black and you're the best model of it." However, in describing being part of a Black community, it came from a sense of empowerment, rather than a role pushed upon them by White peers/faculty as described in the previous themes. Participants did not only describe obligations to the Black community via representation, but also via action. Kelly expressed a desire to be a mentor to incoming Black students because, I definitely have had a lot of opportunities, but I feel like if I had a mentor, if I had somebody that I could relate to, it probably would have been a lot easier. It motivates me because now I want to get somewhere where I would be able to help somebody and they wouldn't have to go through all the nonsense that I went through to get to where I'm at. Similarly, Gayle described her challenges as motivation for helping other Black students, I often question myself as far as, "can I really do that, do I really belong here?" because I don't see, as far as faculty goes, there are no African American females within the college... it's sad and it's upsetting, but at the same time it's just, "okay, you can't let the fact that there are no African American females as far as faculty go deter you from being able to succeed." I feel being Black within the university pushes me to be better and to 
want to have other African Americans be able to do the same things that I was able to do. Gayle goes on to say that she makes sure that there is a Black student presence on the university governing board because it was an opportunity that she had and one that she sees as important.

Participants have motivation to be leaders and provide opportunities for Black students. However, this created pressure for students as well because as Monica stated, 'Now that I'm in a primarily White environment, I feel that drive twice as hard. I have to be on my shit 24-7, or go above and beyond, just to feel like I'm representing my race well." Similarly, Gayle described, "I have to be representative of the entire African American community when it really shouldn't be a weight on my shoulders alone. But I would not identify as anything else because being Black made me have to work harder." For these students there was tension as they felt empowerment and stress at PWIs as they sought to support and be a representation of the Black community. Students discussed being engaged in leadership within the Black community on their campus or college town. This included the Black Student Union, African or Caribbean Student Associations, Black Greek organizations, and service/mentoring groups. Sheila explained "I'm a part of a mentoring program here on campus for students that identify with the African diaspora and it's a one-on-one mentorship between an upper class student and a first year student."

Students also described their future plans for engaging in the Black community, which often was connected to their professional goals. Kelly explained her responsibility to serve, We as a community need to focus [on] getting back in touch with our roots...That's something that's important to me... We have to get back to those times where we're making sure that we as a community are good, and looking out for each other.

This desire to focus one's engagement on the Black community and pursue racial uplift was common. Most described wanting to get involved in public service or outreach related careers 
even if that was not the main focus of their major. For example, one student in STEM expressed, I want to land somewhere where I'm teaching or running a Black student inclusion in science outreach program. I don't think that I can just be a straight scientist or researcher. I can't just sit here and study plants, I need to be involved in my community.

For this participant, despite being trained to become a scientist who traditionally works in a lab, being involved and engaging in outreach is more desirable. Additionally, a student in criminal justice described a desire to get involved in reducing Black incarceration,

I want to be a case manager or a correctional treatment specialist, working directly with adult male offenders, specifically African American. Stop the mass incarceration and slow down recidivism rates...helping offenders figure out their plan for when they get out so they don't come back into the system. You know, what barriers do they have to cross when they get out? What type of programming are they interested in if they want to continue school? How to get them out on their feet.

These narratives demonstrate the desire for students to engage in action and make change within their racial community. They are aware of the challenges that Blacks face in overcoming systemic barriers in order to participate in STEM or deal with the legal system and plan to use the skills, knowledge, and credentials they will have attained in college to fight for racial justice. Students described how their racial identity and college experiences were connected in fostering their professional endeavors as Frank explained, "One of my goals is to, or be involved in, running a university. I have a unique perspective on the approach to police brutality and in violence, and then discrimination and violence on college campuses toward African American folk." Similarly Kelly expressed, "I'm interested in education policies, mentoring students, teaching students because I just feel like at this point I've become more self-aware when it comes 
to my race and my identity." Participants drew from experiences with racialization and racism throughout their lives, but particularly on their campuses, as a driver in their endeavors.

A number of students said going to graduate school would help in achieving their goals, I want to get my $\mathrm{PhD}$ in developmental psychology focusing on racial identity development in Black and Brown kids...I'm fond of the education system because if you're working with kids, that's where they spend the most time. How education supports or fails to support identity in Black and Brown kids, and what are steps we can take (Liz) As students experienced the highly racialized nature of their campuses, they were becoming more aware of how they could positively impact issues of race/racism through their future goals.

\section{Discussion}

We discuss four issues that support and advance scholarly understanding of Black students' experiences with racial climate as well as the DLE. The first reinforces the need to understand how universities are connected to systems and structures within broader society. Hurtado et al. (2012) state, "institutions do not exist in a vacuum, but rather are part of communities and individual external commitments and macrosystems or the contextual forces outside the institution" (p. 49). Unfortunately, this claim has remained more of a conceptual construct than one that is often explicitly emphasized in research and practice. Much of the literature on campus racial climate focuses exclusively on the institutional context (e.g., structural, behavioral, psychological factors) (Mendez \& Cabrera, 2015). Yet, Black students’ narratives in this study highlight that campuses reflect the larger U.S. culture or "macrosystem" (Bronfenbrenner, 1979; Hurtado \& Guillermo-Wann, 2013). As outlined in the DLE (Hurtado et al., 2012) while it is important that universities work to improve the racial climate on their campuses, this work must be situated within the local community environment, policy arena, and 
socio-historical context that universities operate with and within.

Secondly, while the DLE emphasizes the exosystem and macrosystem (Hurtado et al., 2012), it does not explicitly reference the contemporary climate for diversity/racial climate in U.S. society. This climate is a mesosystem factor that has a direct impact on policy agendas, local community climate, and, as we argue, campus climate. Our study contributes to the discourse on Black students' educational experiences by demonstrating the interconnected nature of campus racial climate and the racial climate of U.S. society for students. Participants demonstrated how the systemic racism being resisted through larger movements such as BLM is also reflected and reproduced in U.S. universities. Participants also highlight that while their White peers can ignore this connection or remain at arm's length from societal racial issues, for Black students the issues happening in society are a racial mirror of what is happening on their campuses. This finding takes extant research that demonstrates different racial groups experience and react to their campus racial climates in different ways (Museus, Nichols, \& Lambert, 2008) a step further by showing the nuances in how Black students experience and react to societal racial climate in ways they perceive as distinct from their White peers. These racialized contexts (campus and societal) are interwoven for minoritized students and this must be acknowledged and engaged in order for universities to actively promote inclusion at multiple levels.

Third, our study advances our understanding of community context and external commitments, which the DLE outlines as impacting campus climate for diversity (Hurtado et al., 2012). Scholars highlight how students' external commitments to their local communities and families can have positive and negative effects on retention (Author, in press; Tseng, 2004). For example, low-income students may feel an obligation to help their families while in college by working or helping out at home while other family members work (Titus, 2006). Yet, 
participants in our study describe a different kind of external commitment than what has been described in the DLE. Rather than a more easily defined unit such as family or hometown, these students expressed a commitment to the Black community as a driving force in their campus engagement and future goals. Participants felt a responsibility to act as an agent for change within the Black community given their positionalities as college students. This sense of deep commitment towards maintaining the vitality of the Black community may not have originated during their time in college, but it was clearly developed and reinforced by the racial tensions occurring in U.S. society and students' experiences with race and racism on their campuses.

Lastly, our findings complicate the understanding of how climate for diversity and external commitment relate to student outcomes. The external commitment to Black community that participants described led to engagement that had a positive impact on participants, but were reinforced by negative racial climate experiences. Their experiences with campus racial climate were in alignment with extant literature, which states that Black students at PWIs often experience isolation due to racial prejudice, lack of structural diversity, and discrimination (Author, 2016; Harper \& Hurtado, 2007; Milem et al., 2005). One might conclude that this would negatively impact participants' retention and achievement (outcomes of the DLE). However, our study demonstrates that even with these struggles, Black students continue to find ways to positively connect to their racial identity through activism and engagement in the Black community on and off campus, which also reinforced their persistence. In some ways, this commitment to the Black community reflects values of diversity, equity, and inclusion that parallel one of the outcomes of DLE (developing competencies for a multicultural world) (Hurtado et al. 2012). Hurtado and colleagues define this outcome as "as a set of skills and abilities needed to interact with individuals from different social identity groups, and to make 
ethical decisions in a society marked by inequality and conflict" (pp. 52-54). Our findings extend this to consider how Black students learn to navigate how they are negatively perceived and treated by others, which unfortunately, is a skill that is also needed in today's U.S. racial climate.

\section{Implications}

Although Black students' experiences with campus racial climate at PWIs have been researched, our study demonstrates there are areas for further investigation. Researchers should continue to investigate the interplay between the university context with the political, sociohistorical, and racial climate of broader society. For example, because social and news media play such a major role in how issues of race and racism are portrayed in the U.S., scholars should consider how messaging from these outlets impact campuses' racial climate and minoritized students. Another related topic for inquiry is how students' experiences on campus influence their activism outside of campus as well as how students' non-university connected activism/ engagement in societal issues impact their on campus engagement and outcomes.

We demonstrate that Black students perceive a responsibility to their racial community, which is reinforced by negative experiences at their PWIs. This external commitment may help counter the negative experiences and thus have a positive impact on their success; however, it is beyond the scope of this article to draw that conclusion. Future research can examine the relationship between this type of external commitment and college outcomes in order to determine how it impacts students' academic outcomes and civic engagement. For example, using concepts of racial community uplift, community agency, and community pressure to understand the interplay between these and Black students' academic outcomes and well-being.

Our findings have several implications for campus administrators. The results underscore the importance of having resources in place to support Black students when they experience 
racism from various parties on- and off-campus. Support may come in the form of multicultural centers and program houses that have resources specific to the needs of Black students (Landry, 2002), hiring mental health Professionals of Color (as evidence exists that cultural mistrust might prevent some Black students from seeking help from White counselors; Nickerson, Helms, \& Terrell, 1994) or hiring White counselors who are trained in centering Black students' unique experiences (Guiffrida \& Douthit, 2010). Additionally, mentorship from faculty can create spaces for Black students to not only share and process their experiences, but also maintain motivation to continue studies (Griffin, Perez, Holmes, \& Mayo, 2010). While these forms of support are not new, we name them because across the U.S., PWIs are cutting resources to multicultural centers, aggregating resources targeting Black students into more generalized diversity programming, and creating systems in which Black student organizations compete with other cultural organizations for funding (Patton, 2006). Further, Black Studies programs are being eradicated or aggregated into other academic programs and there is continued underrepresentation of Black faculty and counseling staff (Rooks, 2007; Turner Kelly, Gaston Gayles, \& Williams, 2017). This shift away from resources supporting the specific needs of Black students is problematic given the findings of this study and we recommend universities ensure they are aligning their resources with the needs of Black students to ensure their success. Our recommendations for supporting Black students might have the added benefit of creating a more welcoming campus racial climate, but do not ensure it. In order to create a more positive campus racial climate, diversity, inclusion, and social justice must be integrated into campus environment and culture. As our findings demonstrate, White students and faculty can "opt out" of engaging and grappling with racial issues happening in broader society, which then impacts campus climate for diversity. Thus, any resources, interventions, or programs developed 
for improving racial climate must ensure that White campus members are exposed to historical and contemporary racial issues. At the student level, administrators can work with student leaders and groups to create spaces for positive interactions among diverse peers (Locks, Hurtado, Bowman, \& Oseguera, 2008). Structured diversity programming targeting students in the first year, for example, are effective in having them interact with those outside of their own race (Hu \& Kuh, 2003), which is key for intellectual development around race (Hurtado, 2007).

Administrators must name the role their institutions play in reifying racial inequity and racist structures. At some colleges, administrators are acknowledging the role that slaves played in the construction of their campuses and are connecting this to current practices related to the slaves' descendants and to Black communities in the local area (Walters, 2017). This work toward racial reconciliation draws explicit connections between historical and contemporary campus (and societal) contexts. Positive racial climate can be encouraged by acknowledging institutional history and emphasizing the difficult, but critical, change needed through action and policies focused on areas where inclusivity is not realized (Harper \& Hurtado, 2007).

Lastly, because colleges are embedded in towns that have their own political and cultural ideologies, which might conflict with the institutions' ideologies, another implication is the need for colleges to engage and collaborate with their local communities. Town-gown relationships provide colleges and their local communities opportunities to collaborate and effect change in both settings (McComas, Stedman, \& Hart, 2011; Miller \& Shinn, 2005). Our study shows that racial climate in college towns impact Black students' well being. Thus, it is critical that administrators create inroads with local leaders. Doing so would allow stakeholders to find ways to attend to the needs of the community together, foster understanding of the diversity present within the student body, create safe environments (Gallo \& Davis, 2009). 
PWIs need to look both inwardly and outwardly when working to improve their campus racial climate and the experiences of minoritized students. Our participants illustrate that they cannot disconnect their campus experience from the systemic racism occurring in broader society. Participants also expressed that their PWIs are not properly acknowledging these issues or effectively helping students navigate them. Thus, we call for PWIs to not act as isolated Ivory Towers, but instead recognize their role and position within the racial ecosystem of U.S. society. 


\section{References}

Ancis, J. R., Sedlacek, W. E., and Mohr, J. J. (2000). Student perceptions of campus cultural climate by race. Journal of Counseling and Counseling Development, 78(2), 180-185.

Black Liberation Collective. (2015, December 3). The demands. Retrieved December 6, 2015, from http://www.thedemands.org/

Bronfenbrenner, U. (1979). The ecology of human development. Experiments by nature and design. Cambridge, MA: Harvard University Press.

Bronfenbrenner, U. (Ed.). (2005). Making human beings human: Bioecological perspectives on human development. Thousand Oaks, CA: Sage.

Cabrera, A. F., \& Nora, A. (1994). College students' perceptions of prejudice and discrimination and their Feelings of alienation: A construct validation approach. Review of Education/Pedagogy/Cultural Studies, 16(3), 387-409.

Charmaz, K. (2006). Constructing grounded theory: A practical guide through qualitative analysis. Thousand Oaks, CA: Sage Publications.

Edman, J. L., \& Brazil, B. (2007). Perceptions of campus climate, academic efficacy and academic success among community college students: An ethnic comparison. Social Psychology of Education, 12, 371-383.

Espinosa, L., Chessman, H. \& Wayt, L. (2016, March 8). Racial climate on campus: A survey of college presidents. Higher Education Today: A Blog by ACE American Council on Education. Retrieved from https://www.higheredtoday.org/2016/03/08/racial-climate-oncampus-a-survey-of-college-presidents/

Gallo, R. \& Davis, R. (2009). The impact of town-gown relationships on the sustainability of African American communities: An examination of the role of HBCUs. Journal of 
African American Studies, 13, 509-523. doi: 10.1007/s12111-008-9052-7

Griffin, K.A., Perez II, D., Holmes, A.P.E., \& Mayo, C.E.P. (2010). Investing in the future: The importance of faculty mentoring in the development of students of color in STEM. New Directions for Institutional Research, 148, 95-103. doi: 10.1002/ir

Guiffrida, D.A. \& Douthit, K.Z. (2010). The Black student experience at predominantly White colleges: Implications for school and college counselors. Journal of Counseling and Development, 88, 311-318. doi: 10.1002/j.1556-66787.2010.tb00027.x

Harper, S. R., \& Hurtado, S. (2007). Nine themes in campus racial climates and implications for institutional transformation. In S. R. Harper, \& L. D. Patton (Eds.), Responding to the realities of race on campus: New directions for student services, (1)120, 7-24. San Francisco: Jossey Bass.

Howell, K. (2016, January 30). Tim Wolfe, ousted Mizzou president blames Black Lives Matter, football team for resignation. The Washington Times. Retrieved from http://www.washingtontimes.com/news/2016/jan/30/tim-wolfe-ousted-mizzou-presidentblame-black-live/

Hu, S. \& Kuh, G.D. (2003). Diversity experiences and college student learning and personal development. Journal of College Student Development, 44, 320-334. doi: 10.1353.csd. 2003.0026

Hurtado, S. (2007). Linking diversity with the educational and civic missions of higher education. The Review of Higher Education, 30, 185-196. doi: 10.1353/rhe.2006.0070

Hurtado, S., Alvarez, C. L., Guillermo-Wann, C., Cuellar, M., \& Arellano, L. (2012). A model for diverse learning environments. In J. C. Smart \& M. B. Paulsen (Eds.), Higher Education: Handbook of Theory and Research (pp. 41-122). New York: Springer. 
Hurtado, S., \& Guillermo-Wann, C. (2013). Diverse Learning Environments: Assessing and Creating Conditions for Student Success - Final Report to the Ford Foundation. University of California, Los Angeles: Higher Education Research Institute.

Hurtado, S., Milem, J., Clayton-Pedersen, A. R., \& Allen, W. R. (1998). Enhancing campus climates for racial/ethnic diversity: Educational policy and practice. Review of Higher Education, 21(3), 279-302.

Hurtado, S., \& Ruiz, A. (2012). The climate for underrepresented groups and diversity on campus. Higher Education Research Institute at UCLA, 1, 1-4

Johnson, D. R., Soldner, M., Leonard, J. B., Alvarez, P., Inkelas, K. K., Rowan-Kenyon, H. T., et al. (2007). Examining sense of belonging among first-year undergraduates from different racial/ethnic groups. Journal of College Student Development, 48, 525-542.

Krefting, L. (1999). Rigor in qualitative research: The assessment of trustworthiness. In A. Miliniki, Cases in qualitative research: Research reports for discussion and evaluation (pp. 173-181). Los Angeles: Puscale Publications.

Landry, C.C. (2002). Retention of women and people of color: Unique challenges and institutional responses. College Student Retention, 4, 1-13.

Lincoln, Y. S., \& Guba, E. G. (1985). Naturalistic inquiry. Newbury Park, CA: Sage.

Locks, A.M., Hurtado, S., Bowman, N.A., \& Oseguera, L. (2008). Extending notions of campus climate and diversity to students' transition to college. The Review of Higher Education, $31,257-285$.

Maxwell, J. A. (2005). Qualitative research design: An interactive approach (2nd ed. Vol. 41). Thousand Oaks, CA: SAGE Publications.

McComas, K.A., Stedman, R., \& Hart, P.S. (2011). Community support for campus approaches 
to sustainable energy use: The role of "town-gown" relationships. Energy Policy, 39, 2310-2318. doi: 10.1016/j.enpol.2011.01.045

Mendez, J. J. \& Cabrera, N. L. (2015). Targets but not victims: Latina/o college students and Arizona's racial politics. Journal of Hispanic Higher Education, 14(4), 377-391.

Milem, J. F., Chang, M. J., \& Antonio, A. L. (2005). Making diversity work on campus: A research-based perspective. Making Excellence Inclusive, 1, 1-49.

Miller, R. L., \& Shinn, M. (2005). Learning from communities: Overcoming difficulties in dissemination of prevention and promotion efforts. American Journal of Community Psychology, 35(3-4), 169-183.

Museus, S. D., Nichols, A. H., \& Lambert, A. D. (2008). Racial differences in the effects of campus racial climate on degree completion: A structural equation model. Review of Higher Education, 32(1), 107-134.

Nickerson, K.J., Helms, J.E., \& Terrell, F. (1994). Cultural mistrust, opinions about mental illness, and Black students' attitudes toward seeking psychological help from White counselors. Journal of Counseling Psychology, 41, 378-385.

Patton, L. D. (2006). Black culture centers: Still central to student learning. About Campus, $11(2), 2-8$.

Rankin, S. R., \& Reason, R. D. (2005). Differing perceptions: How students of color and white students perceive campus climate for underrepresented groups. Journal of College Student Development, 46(1), 43-61.

Renn, K. A. (2003). Understanding the identities of mixed-race college students through a developmental ecology lens. Journal of College Student Development, 44(3), 383-403.

Rooks, N. M. (2007). White money/black power: The surprising history of African American 
studies and the crisis of race in higher education. Boston, MA: Beacon Press.

Solórzano, D., Ceja, M., \& Yosso, T. (2000). Critical race theory, racial microaggressions, and campus racial climate: The experiences of African American college students. Journal of Negro Education, 69, 60-73.

Suarez-Balcazar, Y., Orellana-Damacela, L., Portillo, N., Rowan, J. M., \& Andrews-Guillen, C. (2003). Experiences of differential treatment among college students of color. The Journal of Higher Education, 74(4), 428-444.

Tierney, W. G. \& Perkins, J. F. (2015). Beyond the ivory tower: Academic work in the $21^{\text {st }}$ century. In G.G. Shaker (Ed.) Faculty work \& the public good: Philanthropy, engagement, and academic professionalism (pp. 185-198). New York: Teachers College Press.

Titus, M. A. (2006). Understanding college degree completion of students with low socioeconomic status: The influence of the institutional financial context. Research in Higher Education, 47(4), 371-398.

Tseng, V. (2004). Family interdependence and academic adjustment in college: Youths from immigrant and U.S.-born families. Child Development, 75(3), 966-983.

Turner Kelly, B., Gaston Gayles J., \& Williams, C. D. (2017). Recruitment without retention: A critical case of Black faculty unrest. The Journal of Negro Education, 86(3), 305-317.

Walters, L. K. (2017). Slavery \& the American university: Discourses of retrospective justice at Harvard \& Brown. Slavery \& Abolition: A Journal of Slave and Post-Slave Studies, 1-26.

Yosso, T., Smith, W., Ceja, M., \& Solórzano, D. (2009). Critical race theory, racial microaggressions, and campus racial climate for Latina/o undergraduates. Harvard Educational Review, 79, 659-690. 